\title{
Characterisation of pathogenic Yersinia enterocolitica serogroups by pulsed-field gel electrophoresis of genomic Notl restriction fragments
}

\author{
ELISABETH SAKEN, A. ROGGENKAMP, STOJANKA ALEKSIC* and J. HEESEMANN $\dagger$
}

Institute for Hygiene and Microbiology, University of Würzburg, Josef-Schneider-Strasse 2, 79080 Würzburg and

*Hygienisches Institut, Markmannstrasse 129a, 20539 Hamburg, Germany

\begin{abstract}
Summary. Enteropathogenic Yersinia enterocolitica is an important cause of human and animal disease. Phenotypic and genotypic characteristics currently used to identify $Y$. enterocolitica are not necessarily sufficient to differentiate pathogenic from non-pathogenic strains or to analyse the epidemiology of yersiniae at a molecular level. To improve the characterisation of Yersinia isolates, NotI restriction fragment length polymorphisms (RFLPs) of chromosomal DNA of more than 100 clinical, animal and environmental isolates were analysed in pulsed-field gel electrophoresis. Highly conserved RFLP patterns with fragments ranging from 15 to $400 \mathrm{~kb}$ were detected within each of $10 \mathrm{Y}$. enterocolitica serogroups tested. Determination of RFLP types makes it possible to discriminate between isolates of different $Y$. enterocolitica serogroups and other Yersinia spp. Moreover, NotI restriction endonuclease analysis allows even subtyping of strains belonging to a unique serogroup-biotype. Identification of NotI fragments hybridising with inv-or ail-homologous sequences was used as an additional discriminating marker. The results indicate that NotI RFLP typing can provide a powerful new tool for the differentiation of clinical $Y$. enterocolitica isolates.
\end{abstract}

\section{Introduction}

Enteropathogenic Yersinia enterocolitica has been recognised as an important cause of human and animal disease. Diarrhoea, gastro-enteritis and mesenteric lymphadenitis are the most frequent clinical manifestations of human yersiniosis. Furthermore, septicaemia, with abscesses in the liver and other organs as well as sequelae such as reactive arthritis and erythema nodosum, have been observed. ${ }^{1} Y$. enterocolitica has been isolated all over the world, with most cases reported from Japan, North America and northern Europe. Whereas serogroups O3, O5,27 and O9 ("European serogroups") are isolated most frequently in Europe, serogroups O8, $\mathrm{O} 13$ and $\mathrm{O} 20$ predominate in America. ${ }^{2-9}$ However, during the last decade the incidence of serogroup $\mathrm{O} 3$ has been increasing in the USA. ${ }^{10,11} Y$. enterocolitica is found in the environment and in domestic and wild animals and birds, but most strains from environmental sources are avirulent. ${ }^{6,7,12}$

Four methods have been established for routine subdivision of $Y$. enterocolitica: serotyping, flagellar antigen typing, biotyping and phage typing., ${ }^{2,8,9,13,14}$ Serotyping in combination with biotyping is usually sufficient in most cases to differentiate between patho-

Received 18 Feb 1994; accepted 16 May 1994.

$\nmid$ Correspondence should be sent to Professor J. Heesemann. genic and non-pathogenic strains. However, in some instances there are misleading results from serotyping alone because, e.g., $\mathrm{O} 8$ antigen is also expressed by non-pathogenic $Y$. enterocolitica $\mathrm{O} 7,8$, or $\mathrm{O} 3$ antigen can be present on $Y$. intermedia or $Y$. frederiksenii. ${ }^{2,8,9,12}$ Recently, a more direct virulence marker became available with the detection of the $70-\mathrm{kb}$ virulence plasmid $\mathrm{pYV}$ which is present in all human pathogenic $Y$. enterocolitica and $Y$. pseudotuberculosis strains. ${ }^{1,4,15-18}$ However, this virulence plasmid can be rapidly lost in isolates subcultured several times at $37^{\circ} \mathrm{C}$ or stored for prolonged periods in the laboratory. ${ }^{1,4,17}$

As more stable virulence-associated genetic markers, the chromosomal loci such as inv and ail, which encode for invasive phenotypes of $Y$. enterocolitica, and $y s t$ which encodes for the heat-stable enterotoxin of $Y$. enterocolitica, have been characterised and evaluated as epidemiological tools. ${ }^{15,19-22}$ However, it was impossible to differentiate between human pathogenic and non-pathogenic (environmental) strains of $Y$. enterocolitica with the inv probe alone. ${ }^{20.21}$ In contrast, the ail probe recognised the majority of human pathogenic serogroups of $Y$. enterocolitica, but not exclusively. ${ }^{20}$ The yst probe was the most reliable virulence marker because it hybridised exclusively to chromosomal DNA of human pathogenic serogroups of $Y$. enterocolitica but not to that of $Y$. pseudo- 
tuberculosis or non-pathogenic environmental Yersinia spp. (except Y. kristensenii). ${ }^{19}$

However, none of these methods (biotyping, serotyping or virulence gene typing) is sufficient to permit a finer degree of differentiation in epidemiological investigations. ${ }^{2.8 .9 .13-15}$ The recent advances in population genetics have provided several new typing methods such as multilocus enzyme electrophoresis (MLEE. defining electrophoretic types by measuring allelic diversity) and pulsed-field gel electrophoresis (PFGE, to resolve genomic macrorestriction fragment length polymorphism) which differentiate isolates indistinguishable by the phenotypic and genotypic procedures mentioned above. ${ }^{2327}$ Two recent studies showed that human pathogenic strains of $Y$. enterocolitica from diverse geographical locations could be divided into 13 and 24 electrophoretic types (ET), respectively, by MLEE. ${ }^{25.28}$ In comparison with small fragment restriction endonuclease analysis of genomic DNA (REAC), the discriminatory power of MLEE typing for $Y$. enterocolitica strains of serogroup $\mathrm{O} 3$ was slightly higher $(0.752$ versus 0.623$)$ than for REAC typing. ${ }^{29}$ Recently, the impact of PFGE on the analysis of the molecular epidemiology of diverse bacterial pathogens has been demonstrated. ${ }^{24,26}$ However, only preliminary results of genomic macrorestriction analysis of Yersinia spp. have been reported hitherto. ${ }^{30}$

In a more detailed and extended survey, macrorestriction fragment (MRF) patterns of chromosomal DNA of $>100$ clinical isolates of $Y$. enterocolitica of various serogroups were analysed. Moreover, hybridisation results with inv and ail probes were included to assign these virulence-associated genes to certain MRFs and to differentiate between pathogenic and non-pathogenic strains.

\section{Materials and methods}

\section{Bacteria}

A total of $109 Y$. enterocolitica isolates of different serogroups and origin and five Yersinia spp. expressing a serogroup $\mathrm{O} 3$ cross-reacting antigen was tested (table I). The strains were either isolated from patients with clinical signs of yersiniosis in Hamburg and Würzburg (Germany) and Turku (Finland) from 1980 to 1990, or strains (mostly of human origin) that had been described previously. ${ }^{25,29}$ A large proportion of these strains has been characterised recently by $\mathrm{O}-$ and $\mathrm{H}$ serotyping, phage typing and MLEE. ${ }^{25}$

\section{Preparation of genomic DNA and restriction endonuclease digests}

For PFGE, genomic DNA was prepared as described previously. ${ }^{24,26}$ Briefly, bacterial cells grown in Luria broth for $16 \mathrm{~h}$ at $27^{\circ} \mathrm{C}$ were harvested into SE buffer ( $75 \mathrm{~mm} \mathrm{NaCl}, 25 \mathrm{~mm}$ EDTA, pH 7.4) and resuspended to an OD of 2.0. This suspension was mixed with an equal volume of melted agarose (GTG
Agarose, Biometra, Göttingen, Germany) $2 \% \mathrm{w} / \mathrm{v}$ and then pipetted into moulds. After solidification at $4^{\circ} \mathrm{C}$, blocks were removed from the moulds and sliced into the slot size of the PFGE-agarose gels. After overnight incubation in 20 volumes of a buffer containing $0.5 \mathrm{M}$ EDTA, pH 9.5, N-lauroyl-sarcosine sodium salt $1 \% \mathrm{w} / \mathrm{v}$ and proteinase $\mathrm{K} 2 \mathrm{mg} / \mathrm{ml}$, the blocks were washed three times with gentle agitation in 15 volumes of TE ( $10 \mathrm{~mm}$ Tris, $5 \mathrm{~mm}$ EDTA, pH 7.5) and stored in TE at $4^{\circ} \mathrm{C}$. These samples could be stored without detectable degradation of DNA for $>2$ years.

For restriction endonuclease digestion of chromosomal DNA, blocks were transferred into 2-ml sterile Eppendorf tubes and equilibrated in $1 \mathrm{ml}$ of Not $\mathrm{l}$ restriction buffer (Pharmacia, Freiburg, Germany) for $6 \mathrm{~h}$ with several changes of buffer. DNA was digested in $0.2 \mathrm{ml}$ of the same buffer containing $10 \mathrm{U}$ of Not for $16 \mathrm{~h}$ at $37^{\circ} \mathrm{C}$.

\section{PFGE}

PFGE was performed with a CHEF system (BioRad, Richmond, CA, USA). Gels containing GTG agarose (Biometra) $1 \% \mathrm{w} / \mathrm{v}$ were run in $0.5 \times \mathrm{TBE}^{32}$ at $8^{\circ} \mathrm{C}$ at a pulse ramping from 8 to $23 \mathrm{~s}$ for $26 \mathrm{~h}$. Lambda concatamers (Pharmacia) and HindIII-cleaved lambda DNA were used as size standards.

\section{Generation of digoxigenin-labelled DNA probes}

Digoxigenin labelling of the DNA probes specific for the chromosomal genes inv and ail was performed by direct PCR amplification from the $Y$. enterocolitica O8 strain WA-314 according to the method described by Lion and Haas. ${ }^{33}$ Specific primers for ail and inv were derived from the open reading frame of the published nucleotide sequences of the $Y$. enterocolitica ail and inv genes. ${ }^{22,24}$ The primers chosen for ail were: Ail-1 (5'-GTCTGTTAATGTGTACGCTGC-3') and Ail-2 (5'-CACCTGGATGCTTGGTGCAG-3'); and for inv were: Inv-1 (5'-GAAAACCGGCGAGAGCGAAGCG-3') and Inv-2 (5'-GGTGTCAGTCGTCACTTTAGA-3'). The expected sizes for the amplified ail and inv products were $574 \mathrm{bp}$ and $352 \mathrm{bp}$, respectively. PCR amplification was performed as follows: (i) denaturation of chromosomal DNA for $30^{\circ} \mathrm{s}$ at $94^{\circ} \mathrm{C}$; (ii) annealing of primers for $1 \mathrm{~min}$ at $58^{\circ} \mathrm{C}$ (ail) and $57^{\circ} \mathrm{C}$ (inv), respectively; and (iii) extension for $3 \mathrm{~min}$ at $72^{\circ} \mathrm{C}$. For purification, the PCR products were electrophoresed in a low melting agarose gel (agarose $2 \% \mathrm{w} / \mathrm{v}$ ); the labelled products were sliced out and denatured by heat before use as gene probes.

\section{Southern blot and filter hybridisation}

Large chromosomal DNA fragments separated by PFGE were transferred to nylon membranes (Zeta probe, BioRad) by vacuum blotting (Vacu gene, Pharmacia) according to the manufacturers' instructions, and fixed at $80^{\circ} \mathrm{C}$ for $2 \mathrm{~h}$. Pre-hybridisation and hybridisation were at $68^{\circ} \mathrm{C}$ in $5 \times \mathrm{SSC}^{32} \mathrm{~N}$-lauroylsarcosine sodium salt $0.1 \% \mathrm{w} / \mathrm{v}, \operatorname{SDS} 0.02 \% \mathrm{w} / \mathrm{v}$ and 
blocking reagent (Boehringer, Mannheim, Germany) $1 \% \mathrm{w} / \mathrm{v}$. Hybrid DNA was detected by an enzyme immunoassay with anti-digoxigenin antibodies conjugated to alkaline phosphatase (Boehringer) according to the manufacturer's protocol.

\section{Results}

\section{NotI RFLP patterns of diverse Y. enterocolitica serogroups}

A total of $109 Y$. enterocolitica strains of different serogroups, isolated in the years 1980-1990, from various sources and countries of origin, were investigated by restriction fragment length polymorphism (RFLP) analysis of genomic DNA. Corresponding to the prevalence of the different serogroups, 54 strains of serogroup O3, 18 of serogroup $\mathrm{O} 9$ and 15 of serogroup O5,27 were investigated. Moreover, individual strains of selected $Y$. enterocolitica serogroups and other Yersinia spp. (table I) which have been described previously were investigated..$^{25,29}$

$Y$. enterocolitica chromosomal DNA prepared in blocks was digested with several "rare cutting" restriction enzymes (NotI, XbaI, SstI and NheI). Cleavage with $N o t I$ resulted in restriction fragment patterns with good resolution for all $Y$. enterocolitica serogroups tested, whereas cleavage with the other enzymes tested gave too many small fragments (SstI, NheI), or too many fragments of the same range of size (XbaI) (results not shown). NotI generated fragments of $15-400 \mathrm{~kb}$ (fig. 1) which were suitable for genotyping. Restriction fragments $>100 \mathrm{~kb}$ were clearly resolved and were considered for comparison and discrimination of banding patterns. Restriction fragment patterns with few differences in number and size of fragments were classified as the basic (or leading) restriction pattern whereas minor deviations in one to three restriction fragments were considered as subtypes (indicated by small letters) of the leading pattern. This approach revealed that Not I RFLP typing clearly differentiated between $Y$. enterocolitica serogroups (table I, fig. 1), i.e., the 10 different $Y$. enterocolitica serogroups tested corresponded to 10 distinct RFLP patterns. Among the "European serogroups", all strains belonging to the same serogroup had a unique RFLP pattern, with few exceptions (see next section, table II, figs 2 and 3). With regard to the number of strains tested, serogroup-specific RFLP types could be defined for the three "European" human pathogenic serogroups: RFLP types of O3, O5,27 and O9 were, therefore, designated as RFLP 3, 5.27 and 9, respectively.

O3 serotyped Yersinia strains. Serogroup-specific RFLP patterns were observed among all serogroup $\mathrm{O} 3$ strains with but few exceptions. The major group (typical O3 serogroup, biotype 4 or 3 ) could be subdivided into five subtypes (RFLP 3a-e, fig. 2). Interestingly, two different RFLP subtypes were recog- nised within one electrophoretic type (ET1 includes RFLP 3a and c, table IV). Two serogroup O3 strains $(328 / 88$ and 8018 , see table I) which did not correspond to the basic RFLP type 3, were aesculinpositive indicating that they were non-pathogenic $Y$. enterocolitica strains.

05,27 serotyped Yersinia strains. From the rarely isolated $Y$. enterocolitica serogroup O5,27, 15 strains were characterised. All but one strain belonged to a unique and serogroup-specific RFLP (denoted RFLP 5.27). Within this RFLP group, three subgroups could be distinguished (fig. 3), dominated by subgroup 5.27a. The three strains described as ET4 belonged to subgroup $5.27 \mathrm{a}$ or $5.27 \mathrm{~b}$. One American isolate of $Y$. enterocolitica 05,27 which was inv- and ail-positive (characteristic of human pathogenic $Y$. enterocolitica strains) exhibited a clearly different pattern from RFLP 5.27, which was also reflected by the size of the ail-positive NotI restriction fragment (table III).

O9 serotyped Yersinia strains. From the second most frequently isolated "European serogroup" O9, 18 strains were characterised; 16 strains showed a similar restriction pattern, denoted RFLP 9, which comprised five subgroups (fig. 3). Four strains that were of ET5 could be divided into three subgroups (RFLP 9a,b and e). Two strains that could not be included in RFLP 9 because of distinct RFLP patterns were inv-positive but ail-negative (table III). These two strains did not belong to biotype 2 (one was aesculinpositive and one belonged to biogroup 3), which is atypical for $Y$. enterocolitica 09 strains. They were isolated from patients with enteric disease by cold enrichment.

Y. enterocolitica strains of biogroup 1B. Most of the "American serogroups" of $Y$. enterocolitica belong to biogroup 1B. The most frequent isolates are of serogroup O8. All the serogroup O8 strains studied hybridised with inv and ail probe. Six strains were completely phenotyped and five of them were identical with regard to the phenotypes biotype, phage type and ET, with slight deviations in $\mathrm{H}$-antigen. Surprisingly, only a few strains of this cluster were identical in their RFLP pattern; most strains (including the incompletely phenotyped strains), showed RFLP patterns with major deviations in the number and size of the restriction fragments (fig. 4). Therefore, the RFLP patterns of the 10 serogroup O8 strains were classified as seven main RFLP types and were designated by capital letters (RFLP 8A-F and RFLP 8X) to emphasise putative early evolutionary divergence. The other biotype 1B strains of serogroups O13, O13a,13b, O20 and $\mathrm{O} 21$ showed distinct serogroup-specific RFLP patterns with the greatest difference within the range of restriction fragments $<200 \mathrm{~kb}$. It is interesting to note that the RFLP patterns of all biotype 1B strains showed some similarity within the high-mol. wt area (> $200 \mathrm{~kb}$, fig. 4). 
Table I. Characteristics of strains used in this study

\begin{tabular}{|c|c|c|c|c|c|c|c|}
\hline Isolate & Source & Origin & HA & BT & PT & ET & RFLP \\
\hline \multicolumn{8}{|c|}{ Y. enterocolitica $\mathrm{O} 1,2 \mathrm{a}, 3(\mathrm{n}=5)$} \\
\hline IP197" & Chinchilla & USA & $a b c$ & 3 & II & 5 & $1,2,3 \mathrm{a}$ \\
\hline IP714: & Chinchilla & USA & $a b c$ & 3 & II & 5 & $1,2,3 \mathrm{a}$ \\
\hline IP132" & Chinchilla & Netherlands & $a b c$ & 3 & II & 6 & $1,2,3 \mathrm{~b}$ \\
\hline \multicolumn{8}{|c|}{$\begin{array}{l}\text { Chinchilla isolates: } \mathrm{n}=2 \quad \text { Germany } \\
Y \text {. enterocolitica O2a.2b,3 }(n=2)\end{array}$} \\
\hline JP1154" & Hare & Belgium & $a b c$ & 5 & $\mathrm{XI}$ & 7 & $2.2 .3 \mathrm{a}$ \\
\hline $\mathrm{JP} 1142^{\mathrm{a}}$ & Hare & Belgium & $a b c$ & 5 & $\mathrm{XI}$ & 8 & $2,2,3 \mathrm{~b}$ \\
\hline \multicolumn{8}{|c|}{$Y$. enterocolitica $\mathrm{O} 3(\mathrm{n}=54)$} \\
\hline $3668^{a}$ & Man & Finland & $a b c$ & 4 & VIII & 1 & $3 a$ \\
\hline $29 \mathrm{C}-46^{\mathrm{a}}$ & Man & Norway & $a b c$ & 4 & VIII & 1 & $3 c$ \\
\hline $29 \mathrm{C}-43 \mathrm{a}^{\mathrm{a}}$ & Man & Norway & $a b c$ & 4 & VIII & $i$ & $3 \mathrm{c}$ \\
\hline$Y 2 a^{a}$ & Pig & Norway & ac & 4 & VIII & 1 & $3 \mathrm{c}$ \\
\hline$Y 325^{\mathrm{a}}$ & Pig & Norway & $a b c$ & 4 & VIII & 1 & $3 \mathrm{c}$ \\
\hline $\mathrm{MCH} 697^{\mathrm{a}}$ & Man & Canada & $a b c$ & 4 & $\mathrm{IXb}$ & 1 & $3 \mathrm{c}$ \\
\hline $8265^{\mathrm{a}}$ & Man & France & $a b c$ & 4 & VIII & 1 & $3 \mathrm{c}$ \\
\hline SW $13123^{\mathrm{a}}$ & Pig & Japan & $\mathrm{ac}$ & 4 & VIII & 1 & $3 \mathrm{c}$ \\
\hline$Y 325^{a}$ & Pig & Norway & $a b c$ & 4 & VIII & 1 & $3 \mathrm{c}$ \\
\hline $4147^{\mathrm{a}}$ & Man & Finland & $a b c$ & 4 & VIII & 1 & $3 c$ \\
\hline M388 & Pig & Japan & - & 3 & II & $i$ & $3 \mathrm{~d}$ \\
\hline SW13711"a & Pig & Japan & - & 3B & II & 1 & $3 e$ \\
\hline$Y 764^{3}$ & Pig & Norway & $a b c$ & 4 & VIII & 2 & $3 c$ \\
\hline$Y-108^{\prime \prime}$ & Man & Germany & nd & 4 & nd & nd & $3 a$ \\
\hline \multicolumn{2}{|c|}{ Patient isolates $\mathrm{n}=34$} & Germany/Finland & & 4 & nd & nd & $3 a$ \\
\hline TY 5613 & Man & Germany & nd & 4 & nd & nd & $3 b$ \\
\hline \multicolumn{2}{|c|}{ Patient isolates $n=4$} & Germany/Finland & & 4 & nd & nd & $3 \mathrm{c}$ \\
\hline $328 / 88$ & Man & Germany & nd & $\mathrm{nd}^{*}$ & nd & nd & NT \\
\hline \multicolumn{8}{|c|}{ Yersinia spp. of serogroup $\mathrm{O} 3(\mathrm{n}=1)$} \\
\hline $8018^{a}$ & Rodent & Norway & abcd & IA & $\mathrm{XI}$ & 15 & NT \\
\hline \multicolumn{8}{|c|}{$Y$. intermedia $\mathrm{O}^{\mathrm{a}}(\mathrm{n}=1)$} \\
\hline $357-36 / 85$ & Water & Germany & $q$ & nd & $\mathrm{XI}$ & 14 & NT \\
\hline \multicolumn{8}{|c|}{$Y$. frederiksenii $\mathrm{O}^{\mathrm{a}}(\mathrm{n}=1)$} \\
\hline $176-36 / 90$ & Water & Germany & $\mathrm{p} 2$ & nd & $\mathrm{XI}$ & 16 & NT \\
\hline Y. kristenseni & $3^{a}(n=1)$ & & & & & & \\
\hline Y332 & Pig & Norway & - & nd & Xo & 18 & NT \\
\hline$Y$. mollaretii & $(n=1)$ & & & & & & \\
\hline $87-36 / 80$ & Man & Germany & $\mathrm{u}$ & 6 & $\mathrm{XI}$ & 17 & NT \\
\hline Y. enterocolit & $05.27(n=$ & & & & & & \\
\hline D $113^{\mathrm{a}}$ & Dog & Japan & $a b c$ & 2 & $\mathrm{Xz}$ & 4 & $5.27 \mathrm{a}$ \\
\hline PA9436 ${ }^{\mathrm{a}}$ & Man & Japan & $a b c$ & 2 & $\mathrm{Xz}$ & 4 & $5.27 \mathrm{a}$ \\
\hline YE873 & Pig & Canada & $a b c$ & 2 & $\mathrm{Xz}$ & 4 & $5.27 \mathrm{~b}$ \\
\hline $\mathrm{H} 567 / 90$ & Man & Germany & $a b c$ & 3 & nd & nd & $5.27 \mathrm{c}$ \\
\hline Patient isolat & $=5$ & various & nd & nd & nd & nd & $5.27 \mathrm{a}$ \\
\hline Patient isolat & $=1$ & Germany & nd & nd & nd & nd & $5.27 \mathrm{~b}$ \\
\hline Patient isolat & $=1$ & Germany & nd & nd & nd & nd & $5.27 \mathrm{c}$ \\
\hline $\mathrm{H} 735 / 86$ & Man & USA & $a b c$ & 3 & nd & nd & NT \\
\hline Animal isolat & $n=2$ & Germany & $a b c$ & 3 & nd & nd & $5.27 \mathrm{a}$ \\
\hline Animal isolat & $n=1$ & Japan & $a b c$ & 2 & nd & nd & $5.27 \mathrm{a}$ \\
\hline Y. enterocolit & $\operatorname{OS}(n=1)$ & & & & & & \\
\hline $\mathrm{NF}-\mathrm{O}^{\prime}$ & Man & Newfoundland & nd & nd & nd & nd & 5 \\
\hline Y. enterocolit & $O 8(n=10)$ & & & & & & \\
\hline YE $653^{\circ}$ & Man & Canada & befiv & $1 \mathrm{~B}$ & $\mathrm{Xz}$ & 10 & $8 \mathrm{~F}$ \\
\hline $\mathrm{A} 2635^{\mathrm{a}}$ & Man & USA & befi & 1B & $\mathrm{Xz}$ & 10 & $8 \mathrm{~B}$ \\
\hline$N Y 81-68^{a}$ & Man & USA & befi & 1B & $\mathrm{Xz}$ & 10 & $8 \mathrm{E}$ \\
\hline WA-314 & Man & USA & befi & $1 \mathrm{~B}$ & nd & nd & $8 \mathrm{~A}$ \\
\hline WA $^{\mathrm{a}}$ & Man & USA & befiv & 1B & $\mathrm{Xz}$ & 10 & $8 B$ \\
\hline $1700^{a}$ & Man & USA & befi & IB & $\mathrm{Xz}$ & 10 & $8 \mathrm{C}$ \\
\hline$A 2628^{b}$ & Man & USA & nd & IB & nd & nd & $8 \mathrm{~B}$ \\
\hline $893 / 87$ & Man & Italy & befi & 1B & nd & nd & $8 \mathrm{D}$ \\
\hline $900 / 90$ & Man & Japan & befi & IB & nd & nd & $8 \mathrm{D}$ \\
\hline $8081^{\mathrm{a}}$ & Man & USA & befi & 1B & $\mathrm{Xz}$ & 11 & $8 \mathrm{X}$ \\
\hline$Y$. enterocolit & $O 9(n=18)$ & & & & & & \\
\hline YE099: & Man & Canada & abv & 2 & $\mathrm{X} 3$ & 5 & $9 \mathrm{a}$ \\
\hline W829 & Pig & Belgium & $a b$ & 2 & $\mathrm{X} 3$ & 5 & $9 b$ \\
\hline 70ulua & Man & Finland & $a b v$ & 2 & $\mathrm{X} 3$ & 5 & $9 \mathrm{e}$ \\
\hline $3315 \mathrm{a}^{\mathrm{a}}$ & Man & Netherlands & abv & 2 & $\mathrm{X} 3$ & 5 & $9 \mathrm{~b}$ \\
\hline Patient isolat & $=5$ & Germany & nd & 2 & nd & nd & $9 \mathrm{a}$ \\
\hline Patient isolat & $=4$ & Germany & nd & 2 & nd & nd & $9 \mathrm{~b}$ \\
\hline Y-96" & Man & Germany & nd & 2 & nd & nd & $9 \mathrm{~b}$ \\
\hline $1744 / 90$ & Man & Germany & nd & 2 & nd & nd & $9 \mathrm{c}$ \\
\hline $\mathrm{PA} 177$ & Man & Japan & $a b c$ & 2 & nd & nd & $9 \mathrm{~d}$ \\
\hline $1034 / 87$ & Man & Germany & nd & $\mathrm{nd}^{*}$ & nd & nd & NT \\
\hline $259 / 88$ & Man & Germany & $\mathrm{ac}$ & 3 & nd & nd & NT \\
\hline Table I conti & on p. 333 & & & & & & \\
\hline
\end{tabular}


Table I. Cont.

\begin{tabular}{|c|c|c|c|c|c|c|c|}
\hline Isolate & Source & Origin & HA & BT & PT & ET & RFLP \\
\hline \multicolumn{8}{|c|}{ Y. enterocolitica $\mathrm{O} 13(\mathrm{n}=2)$} \\
\hline $1209-79^{\mathrm{b}}$ & Man & USA & nd & 1B & nd & nd & $13 \cdot 1$ \\
\hline YE886 $^{\mathrm{a}}$ & Primate & Canada & abi & $1 \mathrm{~B}$ & $\mathrm{Xz}$ & 12 & $13 \cdot 2$ \\
\hline \multicolumn{8}{|c|}{$Y$. enterocolitica $\mathrm{O} 20(\mathrm{n}=1)$} \\
\hline $1223-75-1^{\mathrm{b}}$ & Man & USA & nd & 1B & nd & nd & 20 \\
\hline \multicolumn{8}{|c|}{$Y$. enterocolitica $\mathrm{O} 21(\mathrm{n}=1)$} \\
\hline YE737 & Man & Canada & befi & 1B & $\mathrm{Xz}$ & 13 & 21 \\
\hline
\end{tabular}

a, strains as described in ref. $25 ; b$, strains as described in ref. $4 ; c$, strains as described in ref. 31; NT, non-typable; nd, not determined; HA, flagellar antigen (-, non-motile); BT, biotype; PT, phage type; ET, electrophoretic type; RFLP, NotI restriction fragment length polymorphism type.

*Aesculin positive.

\section{O-serogroup}

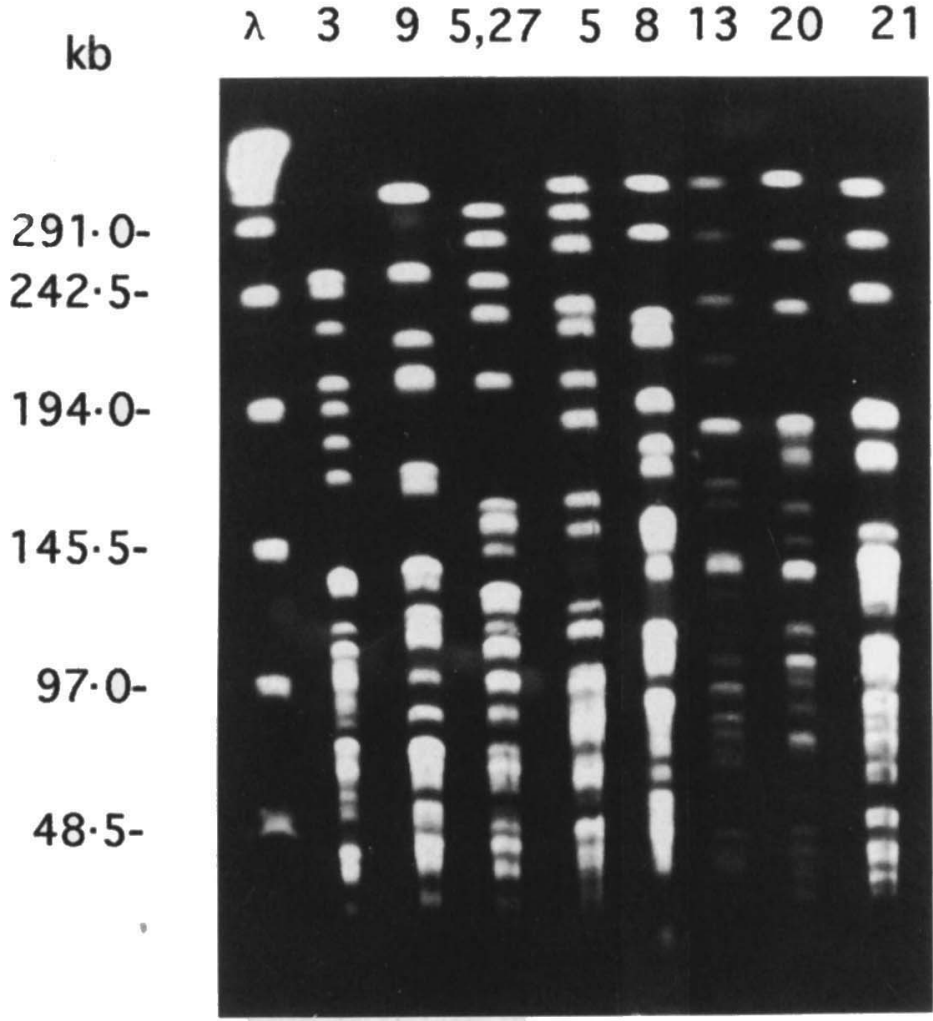

Fig. 1. NotI RFLP of human pathogenic $Y$. enterocolitica serogroups, $\lambda$, phage $\lambda$ concatamers; O3, Y-108; O9, YE099; O5,27, D113; O5, NFO; O8, WA-314; O13, 1209-79; O20, 1223-75-1; O21, YE737.

$01,2 a, 3$ and $02 a, 2 b, 3$ serotyped Yersinia strains. Both serogroups expressed the $\mathrm{O} 3$ antigen, which is shared with $Y$. enterocolitica serogroup $\mathrm{O} 3$ strains. However, the RFLP patterns of these strains were distinct from that of RFLP 3 (fig. 2) and were, therefore, designated according to the serogroup of the strains. Two RFLP subtypes were recognised within each serogroup.

Non-typable strains. The few strains that deviated from the serogroup-specific RFLP type were isolated from asymptomatic carriers or patients with atypical clinical manifestations or were of biotype 1A. These strains were designated "non-typable" (NT) in this study. Five serogroup O3 strains from other Yersinia spp. (table I) were also studied for comparison with the NotI RFLP pattern of $Y$. enterocolitica O3 (fig. 2). These RFLP patterns were clearly distinct from RFLP 3.

Identification of NotI restriction fragments hybridising with inv or ail probe

As a further refinement to the genotypic approach, Southern blot hybridisation with inv and ail probes was used to identify distinct $N o t \mathrm{I}$ restriction fragments. As shown in table III, for all pathogenic $Y$. enterocolitica strains a 90-100 kb NotI restriction fragment hybridised with inv. Y. enterocolitica strains of the same 
Table II. Distribution of variants in RFLP of reference strains and clinical isolates

\begin{tabular}{|c|c|c|c|c|c|c|c|c|c|c|}
\hline \multirow{2}{*}{ Serogroup } & \multirow{2}{*}{$\begin{array}{l}\text { Number of } \\
\text { strains }\end{array}$} & \multirow{2}{*}{ RFLP } & \multirow{2}{*}{$\begin{array}{l}\text { Number of } \\
\text { strains }\end{array}$} & \multicolumn{5}{|c|}{ Number of variants } & & \multirow{2}{*}{ NT } \\
\hline & & & & a & $\mathrm{b}$ & $\mathrm{c}$ & $\mathrm{d}$ & $\mathrm{e}$ & & \\
\hline $\mathrm{O} 1,2,3$ & 5 & 1.2 .3 & 5 & 4 & 1 & 0 & 0 & 0 & & 0 \\
\hline $\mathrm{O} 3$ & 54 & 3 & 53 & 36 & $i$ & 14 & 1 & 1 & & 1 \\
\hline 05.27 & 15 & 5.27 & 14 & 10 & 2 & 2 & 0 & 0 & & 1 \\
\hline $\mathrm{O} 9$ & 18 & 9 & 16 & 6 & 7 & 1 & 1 & 1 & & 2 \\
\hline 08 & 10 & 8 & 9 & $A(1)$ & B (3) & $C(1)$ & $\mathrm{D}(2)$ & $E(1)$ & $F(1)$ & $X(1)$ \\
\hline
\end{tabular}

\section{RFLP}

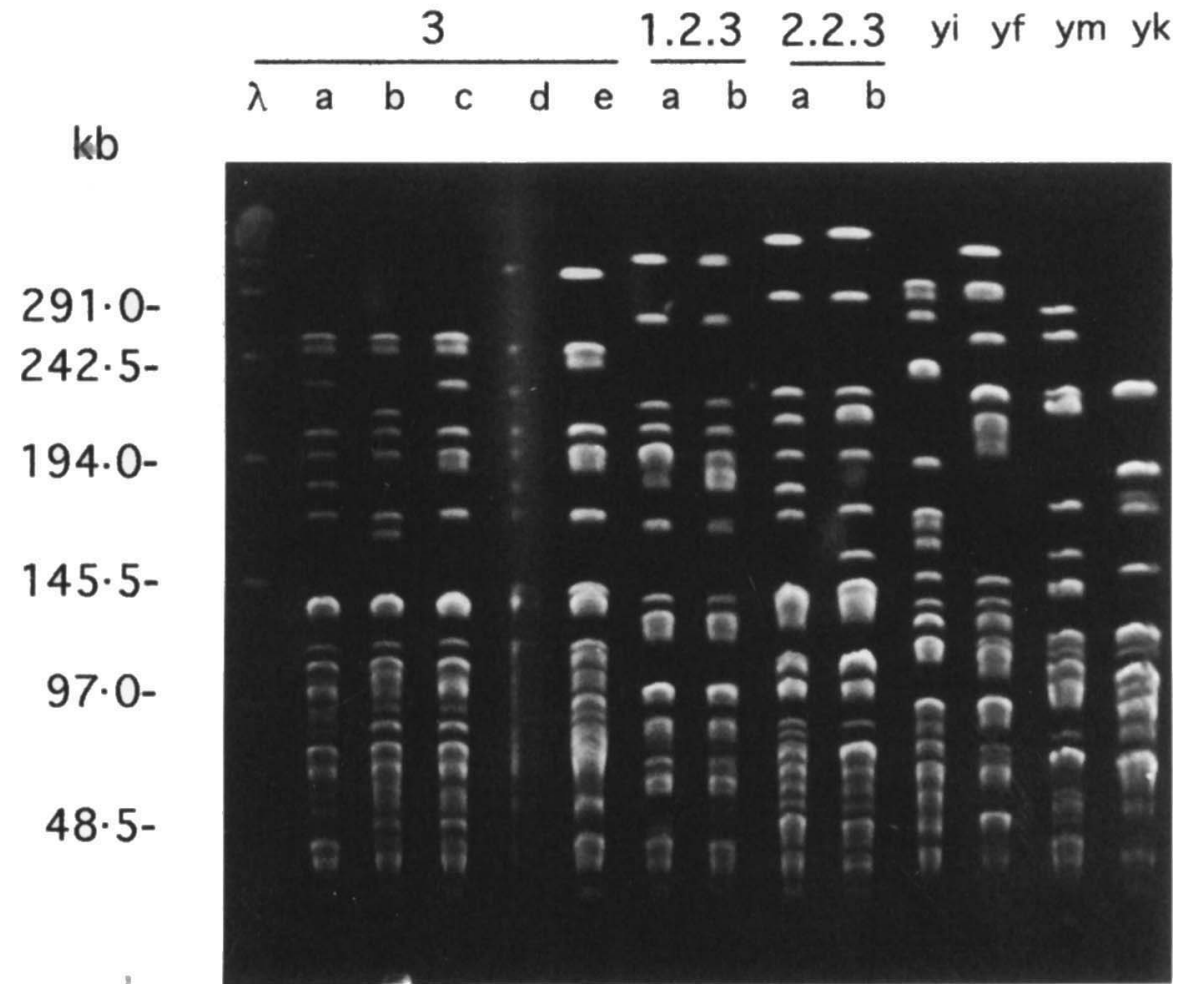

Fig. 2. NotI RFLP patterns and subtypes (indicated by small letters, e.g., RFLP3a) of Yersinia serogroup O3 strains. $\lambda$, phage $\lambda$ concatamers; RFLP 3, 1.2.3 and 2.2.3, Y. enterocolitica; RFLP3a, Y-108; RFLP3b, TY 5613/86; RFLP3c, 29C-46; RFLP3d, M388; RFLP3e, SW13711; RFLP1.2.3a, IP197; RFLP1.2.3b, IP132; RFLP2.2.3a, JP1154; RFLP2.2.3b, JP1142; yi, Y. intermedia; yf, Y.frederiksenii; ym, Y. mollaretii; yk, Y. kristensenii.

serogroup (excluding serogroup O8) showed a unique $i n$-positive NotI restriction band. However, hybridisation with the ail probe revealed a significant RFLP among strains of the same serogroup except for serogroup O3 and O9 strains. These strains of "European serogroups" were highly conserved with regard to the ail-positive NotI restriction fragments.

Comparison of phenotypic and genotypic methods applied to serogroup $\mathrm{O3}$ Yersinia strains

An effective epidemiological analysis requires discriminatory methods that allow differentiation among isolates of the same species. In table IV, the phenotypes such as biotype, phage type and ET are compared with the NotI RFLP types (genotype) of pathogenic (biotype 4, 3A and 3B) $Y$. enterocolitica strains of serogroup O3. Biotype 4 strains could be subdivided into three RFLP types (RFLP 3a,b and c). Strains of the same phage type, H-antigen type of ET were not inter-related with NotI RFLP types. Interestingly, the two biotype 3 strains from Japan could be differentiated from those of biotype 4 by RFLP typing, but not by MLEE. Thus, it appears that NotI RFLP typing has a higher discriminatory power than MLEE and Hantigen typing. 


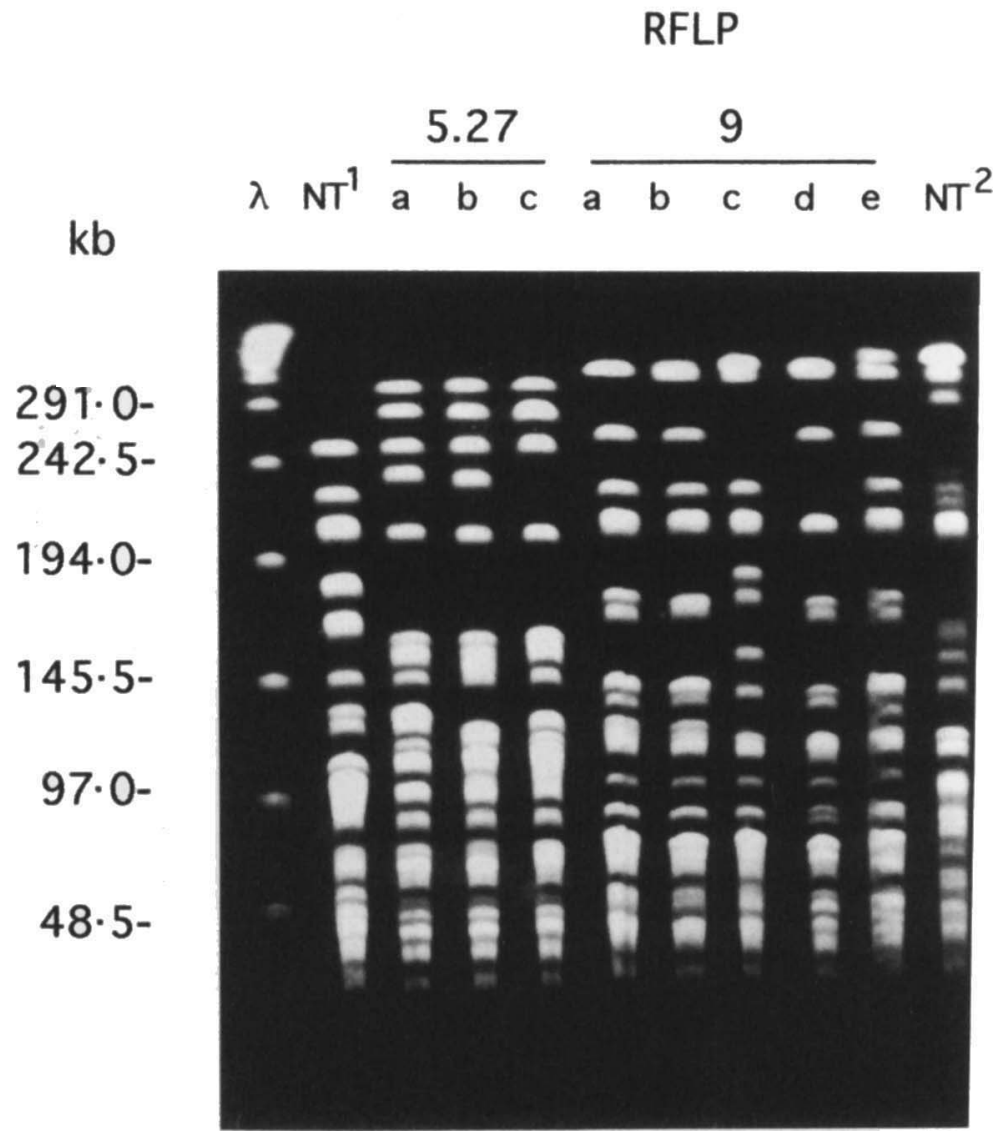

Fig. 3. Not I RFLP patterns and subtypes of $Y$. enterocolitica serogroup 05,27 and $O 9$ strains. $\lambda$, phage $\lambda$ concatamers; RFLP5.27NT ${ }^{\mathbf{1}}$, H735/86; RFLP5.27a, D113; RFLP5.27b, YE873; RFLP5.27c, H567/90; RFLP9a, YE099; RFLP9b, Y-96; RFLP9c, 1744/90; RFLP9d, PA177; RFLP9e, Oulu; RFLP9NT ${ }^{2}$, 1034/87.

Table III. NotI restriction fragments in $\mathrm{kb}$ that hybridised with inv- and ail-specific DNA probes

\begin{tabular}{llcccc}
\hline Strain & RFLP & $\begin{array}{c}\text { Number of } \\
\text { strains tested }\end{array}$ & $\begin{array}{c}\text { Number of } \\
\text { strains } \\
\text { inv-positive* }\end{array}$ & $\begin{array}{c}\text { Number of } \\
\text { strains tested }\end{array}$ & $\begin{array}{c}\text { Number of } \\
\text { strains } \\
\text { ail-positive* }\end{array}$ \\
\hline $\begin{array}{l}\text { Y. enterocolitica } \\
\text { O1,2a,3 }\end{array}$ & $1,2,3 \mathrm{a}$ & 4 & & & \\
& $1,2,3 \mathrm{~b}$ & 1 & $97(4)$ & 4 & $60(4)$ \\
O3 & NT & 0 & $97(1)$ & 1 & $40(1)$ \\
& 3 & 32 & $100(32)$ & 48 & $40(48)$ \\
O5,27 & NT & 1 & $110(1)$ & 1 & $\ldots(0)$ \\
& $5,27 \mathrm{a}, \mathrm{b}$ & 13 & $95(13)$ & 13 & $240(13)$ \\
O8 & $5,27 \mathrm{c}$ & 2 & $95(2)$ & 2 & $300(2)$ \\
& NT & 1 & $95(1)$ & 1 & $55(1)$ \\
O9 & 8 & 9 & $80-90(9)$ & 9 & $120-150(9)$ \\
& $8 \mathrm{X}$ & 1 & $90(1)$ & 1 & $150(1)$ \\
& 9 & 15 & $100(15)$ & 15 & $40(15)$ \\
\hline
\end{tabular}

*Size of positive NotI fragment and number of positive strains.

\section{Discussion}

The PFGE technique can be used to separate large fragments of bacterial DNA generated by "rarecutting" restriction endonucleases. The resulting RFLP pattern can be considered as a characteristic DNA fingerprint of a strain. Strains of the same evolutionary lineage should be encompassed by similar or identical RFLP patterns. ${ }^{2,24,26,30}$ In this study, the potential of genomic RFLP typing for epidemiological studies of $Y$. enterocolitica infections and for comparison with diverse phenotyping methods including MLEE was evaluated. For this reason, $Y$.enterocolitica strains which had been extensively phenotyped previously (serotyped, biotyped, phage typed, electrophoretically typed) were selected and additional clinical isolates (serotyped and biotyped) were included. ${ }^{2-4,17,25,29}$ By trial and error, it was found that the "rare-cutting" restriction endonuclease NotI was well suited to generate resolvable clear and well distri- 


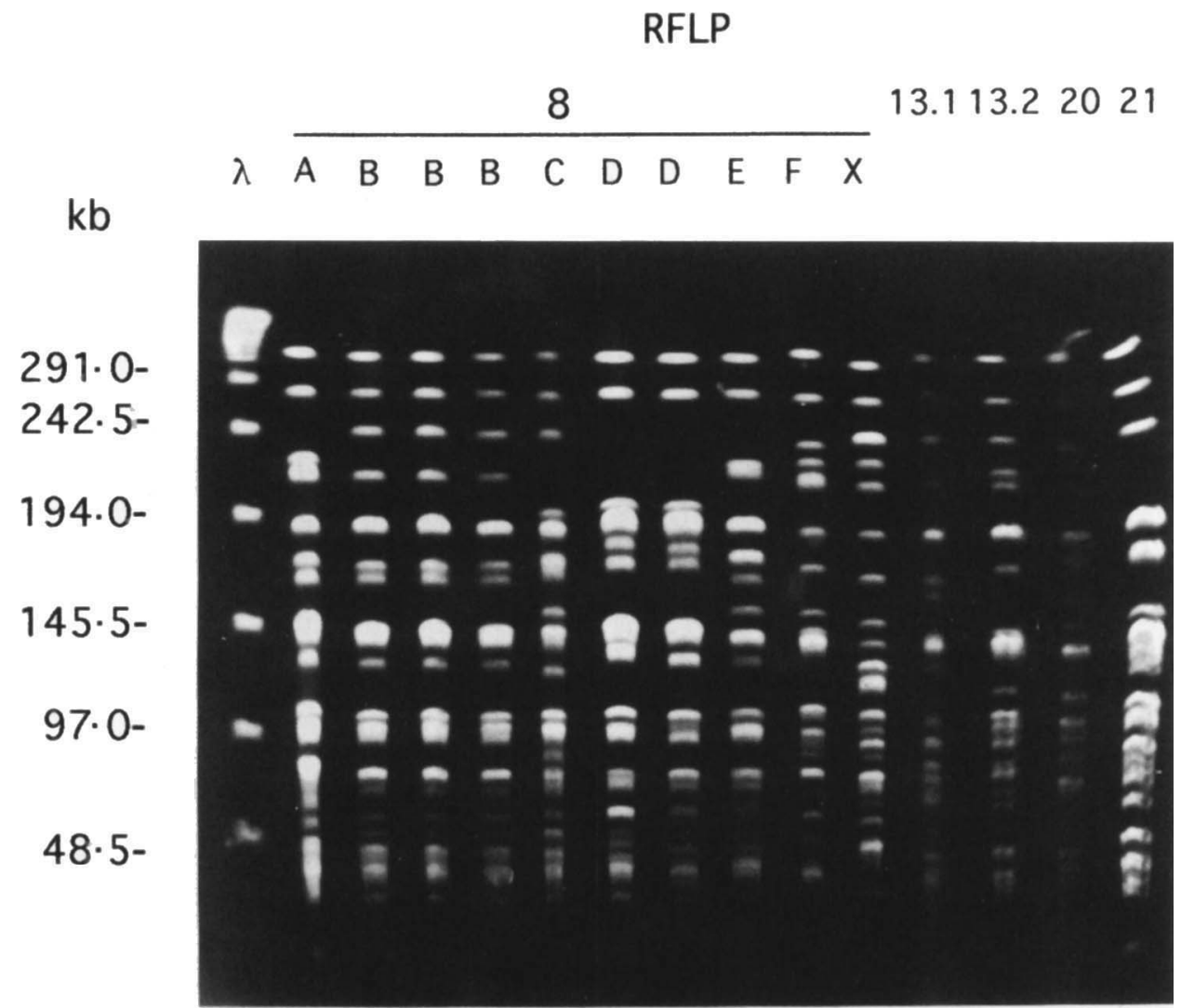

Fig. 4. NotI RFLP patterns and subtypes of $Y$. enterocolitica biogroup 1B strains. $\lambda$, phage $\lambda$ concatamers; RFLP8.A, WA-314; RFLP8.B, WA; RFLP8.B, A2635; RFLP8.B, A2628; RFLP8.C, 1700; RFLP8.D, 893/87; RFLP8.D, 900/90; RFLP8.E, NY81-68; RFLP8.F, YE653; RFLP8.X. 8081; RFLP13.A. 1209-79; RFLP13.B, YE886; RFLP20, (1223-75-1); RFLP21, YE737.

Table IV. Comparison of $Y$. enterocolitica RFLP 3 with other strain characteristics

\begin{tabular}{ccccc}
\hline ET & BT & PT & RFLP & HA \\
\hline $1(13)$ & $4(11)$ & VIII (9) & $3 \mathrm{c}(8)$ & abc (6) \\
& & & $3 \mathrm{ac}(2)$ \\
& & IXb (2) & $3 \mathrm{c}(2)$ & $\mathrm{abc}(1)$ \\
& $3 / 3 \mathrm{~B}(2)$ & II (2) & $3 \mathrm{e}(1)$ & NM (1) \\
& & VIII (1) & $3 \mathrm{da}(1)$ & NM (1) \\
$2(1)$ & $4(1)$ & abc (1) \\
nd & $4(1)$ & nd & $3 \mathrm{~b}(1)$ & nd \\
\hline
\end{tabular}

nd, not determined; number of strains shown in parentheses.

buted MRFs of chromosomal DNA of diverse Yersinia spp. within the range $15-400 \mathrm{~kb}$. Not I-generated RFLP patterns of diverse Yersinia spp. and also of strains of the same $Y$. enterocolitica serogroup were easily distinguishable. Strains which were incorrectly classified by conventional typing techniques were also discovered by RFLP typing (see table I). These results confirmed those of a preliminary MRF study reported recently ${ }^{30}$ and encouraged us to focus our interest on the most frequently isolated human pathogenic serogroups of $Y$. enterocolitica.

For several reasons, there is a need for refinement of differentiation techniques to study the molecular epidemiology of yersinia infections. Previously, we and others have shown that restriction endonuclease analysis of yersinia virulence plasmids (REAP-typing) can hardly differentiate among strains of the same serogroup (except serogroup 08). ${ }^{16-18}$ This prompted several epidemiologists to evaluate restriction enzyme analysis of chromosomal DNA (REAC) of Yersinia spp. as a useful genotyping method. ${ }^{10,29}$ However, as REAC is complicated by the high number of small restriction fragments generated by frequent-cutting endonucleases, this proved to be of low differentiating potential. For instance, $Y$. enterocolitica strains of serogroup $\mathrm{O} 3$ but different phage types could not be differentiated by REAC-typing. ${ }^{29}$ An improvement of the REAC method was achieved when rRNA probes were used for detecting specific RFLPs (ribotyping). There are three relevant reports of the differentiation of Yersinia strains by ribotyping. ${ }^{10,28,35}$ PicardPasquier et al. used rRNA probes for HindIII- and EcoRI-digested chromosomal DNA of yersiniae. ${ }^{28}$ Surprisingly, they were unable to differentiate between strains of the same biotype. With the restriction endonuclease $N c i$ in conjunction with an rRNA probe, two research groups were able to discriminate five and four different ribotypes, respectively, within serogroup $\mathrm{O} 3$ strains. $^{10.35} \mathrm{~A}$ close inter-relation between ribotypes I and II and phage types IXb and VIII of $Y$. enterocolitica $\mathrm{O} 3$, respectively, was demonstrated. However, ribotyping was unable to differentiate between strains of serotype 01,2,3 and 09 . Attempts to improve the discriminatory potential by 
MLEE also failed because strains of the same $O$ serogroup were also of the same ET and strains of different serogroups could be of the same ET and thus could not be distinguished. ${ }^{25}$

By RFLP typing with restriction endonuclease Not $\mathrm{I}$, the "European serogroups" O3, O9 and O5,27 could be clustered in serogroup-specific RFLP patterns (RFLP 3, RFLP 9 and RFLP 5.27), each consisting of several sub-patterns which could be distinguished by minor deviations of one to three restriction fragments. For instance, the 54 strains of $Y$. enterocolitica of serogroup O3-biotype 4 studied could be subdivided into three RFLP 3 subtypes (designated by small letters, RFLP 3a-c). Most strains of serogroup O3biotype 4 were distributed among RFLP $3 \mathrm{a}$ and $\mathrm{c}$.

Considering serogroup O3-biotype 4 strains, electrophoretic types (all but one strain were ET1), phage types (PT VIII, PT IXb) and $\mathrm{H}$-antigen types did not correspond to distinct RFLP subtypes (tables I and IV) ${ }^{25}$ However, the majority of the Finnish isolates of REAP type I were RFLP 3c and those of REAP type II were RFLP 3a, respectively (results not shown; P. Toivanen, personal communication).

In contrast to ribotyping, RFLP typing clearly distinguished biogroup $3 Y$. enterocolitica strains expressing the $\mathrm{O} 3$ antigen from those of biogroup 4. ${ }^{10,28,35}$ The RFLP patterns of the two Japanese serogroup O3 isolates (RFLP $3 \mathrm{~d}$ and e) and the five Chinchilla isolates of serogroup O1,2a,3 (RFLP 1.2.3a and $b$ ) could be clearly distinguished from serogroup O3-biotype 4 strains by major deviations of the RFLP 3 pattern. Thus, RFLP typing of $Y$. enterocolitica strains expressing the $\mathrm{O} 3$ antigen in conjunction with phage typing has a higher discriminatory potential than ribotyping (with $N c i$-RFLP types).

A similar conclusion could be drawn from the $\mathrm{O} 9$ and 05,27 strains, that both belong to biogroup 2 but to phage types $\mathrm{X} 3$ and $\mathrm{Xz}$, respectively. Fourteen strains of serogroup O5,27 and 16 strains of serogroup O9 were subdivided into three and five RFLP subtypes, respectively. Strikingly, O9 strains were preferentially of RFLP 9a or b and O5,27 strains accumulated as RFLP 5,27a. In contrast, ribotyping of O5,27 strains was less efficient. ${ }^{10,35}$ The five O5,27 strains which had been ribotyped were all of NciI-RFLP type b; however, serogroup O3-biogroup 3 strains also belonged to this ribotype..$^{35}$ Unfortunately, representative ribotyping results of $Y$. enterocolitica of serogroup $\mathrm{O} 9$ are not available for comparison with RFLP types.

RFLP typing of 10 serogroup O8 $Y$. enterocolitica strains of different origin revealed seven RFLP pat-

\section{References}

1. Cornelis G, Laroche Y, Balligand G, Sory MP, Wauters G. Yersinia enterocolitica, a primary model for bacterial invasiveness. Rev Infect Dis 1987; 9: 64-87.

2. Ogasawara M, Kobayashi S, Arai S et al. A heat-modifiable outer membrane protein carries an antigen specific for the species Yersinia enterocolitica and Yersinia pseudotuberculosis. J Immunol 1985; 135 : 1430-1436. terns with major differences in many restriction fragments; therefore, these patterns were allocated capital letters, RFLP 8A, B etc. A similar heterogeneity of serogroup $\mathrm{O} 8$ strains had been found by REAP typing (six plasmid variants), from ribotyping (four NcilRFLP types) and from REAC typing (10 REAC types of 10 strains). ${ }^{18,25,29,35}$ Surprisingly, serogroup O8 strains appeared homogeneous according to phage type (Xz), biogroup (1B) and ET (ET10).

It is striking that the serogroup O8 strain 8081 could be easily distinguished from the other $\mathrm{O} 8$ strains by diverse genotypic techniques. This singularity of strain 8081 is particularly emphasised by the ET11 and the RFLP type 8X. In contrast to the heterogeneity of the RFLP patterns of biogroup 1B strains (including serogroups $\mathrm{O} 8, \mathrm{O} 13, \mathrm{O} 20$ and $\mathrm{O} 21$ ), these strains share several features: (i) geographical restriction to North America; (ii) high virulence for rodents; (iii) sensitivity to pesticin; (iv) siderophore production; and (v) broad host range. ${ }^{1,4,7,36-38}$ From this aspect, biogroup 1B strains may belong to the same evolutionary lineage. Taking into account the fact that mobile genetic elements (e.g., insertion sequences) render biogroup $1 \mathrm{~B}$ strains particularly genetically unstable, genetically diverging lineages of one evolutionary clone would be expected. This assumption might explain the relatively low degree of similarity of all RFLP patterns obtained from biogroup 1B strains and it is supported by two recent reports about the genomic instability of $Y$. pestis and $Y$. pseudotuberculosis. ${ }^{39,40}$ The biogroup 1B strains may benefit from genetical instability because of probable better adaptation to a broad host range and to survival in the environment. ${ }^{\text {? }}$

In contrast, the European $Y$. enterocolitica isolates of biogroups 2 and 4 are assumed to be well adapted to pigs (narrow host range) and they are usually not found in the environment (e.g., river water, soil). Probably, these strains have become genetically stable by convergent evolution, e.g., by loss of transposable elements (transposon, IS-element).

In summary, genomic NotI RFLP typing permits the distinction of $Y$. enterocolitica of different serogroups and also strains of the same serogroup. Because of the discriminatory potential and practicability of PFGE, NotI RFLP typing appears to be more suitable than other genotypic methods (e.g., ribotyping and MLEE) for molecular epidemiological analysis of yersiniosis.

We thank A. Riedmann and C. Klüpfel for technical assistance and I. B. Autenrieth for critical reading of the manuscript. This project was supported by the DFG, grant He 297/2-2.

3. Aleksic S, Bockemühl J, Wuthe HH, Aleksic V. Occurrence and clinical importance of the pathogenic serogroup $0: 5,27$ of Yersinia enterocolitica in the Federal Republic of Germany and methods for its serological and bacteriological identification. Zentralbl Bakteriol Mikrobiol Hyg A 1988; 269: 197-204.

4. Kay BA, Wachsmuth K, Gemski P. New virulence-associated plasmid in Yersinia enterocolitica. J Clin Microbiol 1982; 15: 1161-1163. 
5. Schiemann DA. Fleming CA. Yersinia enterocolitica isolated from throats of swine in eastern and western Canada. Can $J$ Microbiol 1981; 27 : 1326-1333.

6. Shayegani M. DeForge I. McGlynn DM. Root T. Characteristics of Yersinia enterocolitica and related species isolated from human, animal, and environmental sources. $J$ Clin Microbiol 1981; 14: 304-312.

7. Shayegani M, Parsons LM. Epidemiology and pathogenicity of Yersinia enterocolitica in New York State. Contrib Microbiol Immunol 1987; 9: 41-47.

8. Wauters G, Kandolo K, Janssens $\mathbf{M}$. Revised biogrouping scheme of Yersinia enterocolitica. Contrib Microbiol Immunol 1987: 9: 14-21.

9. Wauters G, Aleksic S, Charlier J, Schulze G. Somatic and flagellar antigens of Yersinia enterocolitica and related species. Contrib Microbiol Immunol 1991; 12: 239243.

10. Blumberg HM, Kiehlbauch JA, Wachsmuth IK. Molecular epidemiology of Yersinia enterocolitica $\mathrm{O}: 3$ infections: use of chromosomal DNA restriction fragment length polymorphisms of rRNA genes. $J$ Clin Microbiol 1991; 29 2368-2374.

11. Bissett ML, Powers C, Abbott SL, Janda JM. Epidemiologic investigations of Yersinia enterocolitica and related species sources, frequency, and serogroup distribution. $J$ Clin Microbiol $1990 ; 28$ : $910-912$

12. Fukushima H, Tsubokura M, Otsuki K, Kawaoka Y. Biochemical heterogeneity of serotype-O3 strains of 700 Yersinia strains isolated from humans, other mammals, flies, animal feed, and river water. Curr Microbiol 1984; 11 : $149-183$.

13. Baker PM, Farmer JJ. New bacteriophage typing system for Yersinia enterocolitica, Yersinia kristensenii, Yersinia frederiksenii, and Yersinia intermedia: correlation with serotyping, biotyping, and antibiotic susceptibility. $J$ Clin Microbiol 1982; 15: 491-502.

14. Kapperud G, Bergan T. Biochemical and serological characterization of Yersinia enterocolitica. Methods Microbiol 1984; 15: $296-344$

15. Farmer JJ, Carter GP, Miller VL, Falkow S, Wachsmuth IK Pyrazinamidase, CR-MOX agar, salicin fermentationesculin hydrolysis, and D-xylose fermentation for identifying pathogenic serotypes of Yersinia enterocolitica. $J$ Clin Microbiol 1992; 30: 2589-2594.

16. Fukushima H, Gomyoda M, Aleksic S, Tsubokura M. Differentiation of Yersinia enterocolitica serotype $0: 5,27$ strains by phenotypic and molecular techniques. $J$ Clin Microbiol 1993; 31 : 1672-1674.

17. Heesemann J, Keller C, Morawa R, Schmidt N, Siemens HJ, Laufs R. Plasmids of human strains of Yersinia enterocolitica: molecular relatedness and possible importance for pathogenesis. J Infect Dis 1983; 147: 107-115.

18. Kapperud G. Nesbakken T. Restriction endonuclease analysis of 40- to 50-Mdalton plasmids from Yersinia enterocolitica strains of worldwide origin. Contrib Microbiol Immunol 1987: 9: 317-323.

19. Delor I, Kaeckenbeeck A, Wauters G, Cornelis GR. Nucleotide sequence of yst, the Yersinia enterocolitica gene encoding the heat-stable enterotoxin, and prevalence of the gene among pathogenic and nonpathogenic yersiniae. Infect Immun 1990; 58: 2983-2988.

20. Miller VL, Farmer JJ, Hill WE, Falkow $S$. The ail locus is found uniquely in Yersinia enterocolitica serotypes commonly associated with disease. Infect Immun 1989; 57: 121-131.

21. Pierson DE, Falkow S. Nonpathogenic isolates of Yersinia enterocolitica do not contain functional inv-homologous sequences. Infect Immun 1990: 58: 1059-1064.
22. Young VB, Miller VL, Falkow S, Schoolnik GK. Sequence, localization and function of the invasin protein of Yersinia enterocolitica. Mol Microbiol 1990; 4: 1119-1128.

23. Arbeit RD, Arthur M, Dunn R, Kim C, Selander RK, Goldstein $R$. Resolution of recent revolutionary divergence among Escherichia coli from related lineages: the application of pulsed field electrophoresis to molecular epidemiology. $J$ Infect Dis 1990; 161: 230-235.

24. Böhm H, Karch $\mathrm{H}$. DNA fingerprinting of Escherichia col O157: H7 strains by pulsed-field gel electrophoresis. $J$ Clin Microbiol 1992; 30: 2169-2172.

25. Caugant DA, Aleksic S, Mollaret HH, Selander RK, Kapperud G. Clonal diversity and relationships among strains of Yersinia enterocolitica. J Clin Microbiol 1989; 27: 26782683.

26. Ott $\mathbf{M}$, Bender $\mathbf{L}$, Blum $\mathrm{G}$ et al. Virulence patterns and longrange genetic mapping of extraintestinal Escherichia coli $\mathrm{K} 1, \mathrm{~K} 5$, and $\mathrm{K} 100$ isolates: use of pulsed-field gel electrophoresis. Infect Immun 1991: 59: 2664-2672.

27. Selander RK, Musser JM, Caugant DA, Gilmour MN, Whittam TS. Population genetics of pathogenic bacteria. Microb Pathog 1987; 3: 1-7.

28. Picard Pasquier N, Picard B, Heeralal S, Krishnamoorthy R, Goullet P. Correlation between ribosomal DNA polymorphism and electrophoretic enzyme polymorphism in Yersinia. J Gen Microbiol 1990; 136: 1655-1666.

29. Kapperud G, Nesbakken T, Aleksic S, Mollaret HH. Comparison of restriction endonuclease analysis and phenotypic typing methods for differentiation of Yersinia enterocolitica isolates. J Clin Microbiol 1990; 28: 1125-1131.

30. Iteman I, Baril C, Saint Girons I, Carniel E. Pulse field electrophoresis of the chromosome of the pathogenic yersiniae. Contrib Microbiol Immunol 1991; 12: 198-202.

31. Heesemann J, Algermissen B, Laufs R. Genetically manipulated virulence of Yersinia enterocolitica. Infect Immun 1984; 46: $105-110$.

32. Maniatis T, Fritsch EF, Sambrook J. Molecular cloning: a laboratory manual. Cold Spring Harbor, NY, Cold Spring Harbor Laboratory. 1982.

33. Lion T, Haas OA. Nonradioactive labeling of probe with digoxigenin by polymerase chain reaction. Anal Biochem $1990 ; 188$ : $335-337$

34. Miller VL, Bliska JB, Falkow S. Nucleotide sequence of the Yersinia enterocolitica ail gene and characterization of the Ail protein product. $J$ Bacteriol $1990 ; 172$ : $1062-1069$.

35. Andersen JK, Saunders NA. Epidemiological typing of Yersinia enterocolitica by analysis of restriction fragment length polymorphisms with a cloned ribosomal RNA gene. $J$ Med Microbiol 1990; 32: 179-187.

36. Heesemann J. Chromosomal-encoded siderophores are required for mouse virulence of enteropathogenic Yersinia species. FEMS Microbiol Lett 1987; 48: 229-233.

37. Heesemann J, Hantke $\mathrm{K}$, Vocke $\mathrm{T}$ et al. Virulence of Yersinia enterocolitica is closely associated with siderophore production, expression of an iron-repressible outer membrane polypeptide of $65000 \mathrm{Da}$ and pesticin sensitivity. Mol Microbiol 1993; 8: 397-408.

38. Heesemann J, Gaede K, Autenrieth IB. Experimental Yersinia enterocolitica infection in rodents: a model for human yersiniosis. APMIS 1993; 101: 417-429.

39. de Almeida AM, Guiyoule A, Guilvout I, Iteman I, Baranton G, Carniel E. Chromosomal irp 2 gene in Yersinia: distribution, expression, deletion and impact on virulence. Microb Pathog 1993; 14: 9-21.

40. Lucier TS, Brubaker RR. Determination of genome size, macrorestriction pattern polymorphism, and nonpigementation-specific deletion in Yersinia pestis by pulsed-field gel electrophoresis. J Bacteriol 1992; 174: 2078-2086. 